\title{
In silico binding affinity analysis of microplastic compounds on PET hydrolase enzyme target of Ideonella sakaiensis
}

\author{
Chidi Edbert Duru ${ }^{*}$ (D), ljeoma Akunna Duru² and Christian Ebere Enyoh ${ }^{3}$
}

\begin{abstract}
Background: The world today is faced with the humongous challenge of removing the numerous plastic wastes in our environment. Efforts in the removal or remediation of these materials from the ecosystem are presently at the budding stage. Some researchers have shown that certain bacterial enzymes have the ability to hydrolyze and further degrade these plastic compounds. In this study, the ability of PET hydrolase enzyme to hydrolyze polyvinylchloride, polyurethane, polymethyl methacrylate, polyamide, polyethylene terephthalate, and polycarbonate was investigated in silico.

Results: The binding affinity values of polycarbonate $(-5.7 \mathrm{kcal} / \mathrm{mol})$ and polyethylene terephthalate $(-5.2 \mathrm{kcal} /$ $\mathrm{mol}$ ) on the enzyme targets were the highest and showed that they are likely to be efficiently hydrolyzed by this bacteria in the environment. The binding affinity of polyvinylchloride was the lowest $(-2.2 \mathrm{kcal} / \mathrm{mol})$ and suggested that it would show resistance to hydrolysis by the PET hydrolase enzyme.
\end{abstract}

Conclusion: The findings from this study showed that PET hydrolase enzyme from Ideonella sakaiensis could be efficient in the hydrolysis of plastic wastes composed mainly of polycarbonate and polyethylene terephthalate.

Keywords: Microplastic, Ideonella sakaiensis, PET hydrolase, Polycarbonate, Polyethylene terephthalate

\section{Background}

The global production of plastic is on continual growth and rose from 335 million tons in 2016 to 348 million tons in 2017 (Verla et al. 2019a, b; Poerio et al. 2019). The rapid growth has been accompanied by the high waste plastic generation because of specific properties including their light-weight, versatility and durability (Jambeck et al. 2015; Diaz-Torres et al. 2017). These properties also present the key problem with plastic waste being persistent in the environment and so many countries have tried to reverse the situation by banning single-use and encouraged recycling of waste plastics (Verla et al.

\footnotetext{
*Correspondence: chidiedbertduru@gmail.com

1 Surface Chemistry and Environmental Technology (SCENT) Research Unit, Department of Chemistry, Imo State University, PMB 2000, Owerri, Imo State, Nigeria

Full list of author information is available at the end of the article
}

2019a, b). Current data suggests that $10 \%$ of plastic produced annually ended up as waste in the environment (Enyoh et al. 2020). Some plastic materials found in the environment include polypropylene (PP), polycarbonate (PC), expanded polystyrene (PSE), polyarylsulfone (PSU), polystyrene (PS), thermoplastic elastomers (TPE), polyethylene terephthalate (PET), polymethyl methacrylate (PMMA), polyvinyl chloride (PVC), polypropylene (PP), polyamides (PA), fluoropolymer, etc. These are thermoplastics, which are easily reversed by altering temperature while types such as epoxy resins, vinyl ester, polyurethane (PUR), urea-formaldehyde, acrylic resin, silicone, melamine resin, phenolic resins, phenol-formaldehyde and unsaturated polyester are thermosets and not easily reversed (Verla et al. 2019a, b).

The negative effects of having plastic in the environment are numerous. Plastic pollution can lead to the death of big sea animals such as whales, turtles, etc. from 
ingestion or entanglement (Enyoh et al. 2020). Plastics often distribute organisms to areas that are less biologically diverse and not their original habitat as they are transported by wind and ocean current. Furthermore, plastics can also lead to climate change due to emissions from production, transportation, incineration. A recent report showed that about 850 million tons of carbon dioxide is emitted to the atmosphere from plastic production and incineration (CIEL 2019a, b). This estimate is expected to reach 1.34, 56 and 260 billion tons of greenhouse gas emissions by 2030, 2050 and 2100 respectively, exceeding $14-50 \%$ of the global carbon budget in 2050 and 2100 (CIEL 2019a, b). On land, they pose threat to plants by blocking sunlight and thus restricting their growth (Enyoh et al. 2019a, b). Chlorinated plastics may release harmful chemicals into the surrounding soil, which could then flow into groundwater or other nearby bodies of water and into the world's environment (Aggarwal 2019), which can cause serious harm to the waterdrinking animals.

Plastics could be broken down by the action of light or mechanically into smaller size particles called micro (MPs: $0.1 \mu \mathrm{m}$ to $<5 \mathrm{~mm}$ ) and nano (NP: $<100 \mathrm{~nm}$ ) plastics and pose further threat to the ecosystems. The primary risks of MPs and NPs to the ecosystems are their ubiquity and bioavailability for ingestion, entanglement or inhalation (Enyoh et al. 2020). There are multiple reports of their ingestion by marine, soil organisms and plants from polluted soils (Li et al. 2019). They have been found in table salts and potable water (Karami et al. 2017). The health implications of MPs and NPs may be physical by blocking the digestive system due to particle localization, a chemical with associated toxic chemical effects and biological involving toxins (Wright and Kelly 2017; Li et al. 2018; Wang et al. 2020). At the cellular and molecular levels, some studies have demonstrated that MPs or NPs can induce reactive oxygen species (ROS) as well as inhibiting the efflux pump and mitochondria depolarization (Claudia et al. 2020; Wang et al. 2020). Furthermore, they can also affect several signaling pathways, causing fibrosis, autophagy, and even DNA mutations (Wang et al. 2020). Therefore, there is a need to reduce the amount or quantity of plastic waste emitted to safeguard environmental and human health.

River-dominated coastal environments receive $52 \%$ of plastic pollution delivered by rivers and streams (Harris et al. 2021). A wide range of pollutants including organic such polyaromatic hydrocarbons, polychlorinated biphenyls, dichlorodiphenyltrichloroethanes, antibiotics, dyes, oil etc. and inorganic pollutants such as heavy and radioactive metals can be adsorbed by plastic waste in the marine environment (Narciso-Ortiz et al. 2020; Li et al. 2018; Abd-Aziz et al. 2019). The adsorption of pollutants by plastics make them vectors for pollutants over long distances within the marine environment (Verla et al. 2019a, b; Zhang et al. 2020) and in the atmosphere (Enyoh et al. 2019a, b) conferring double danger to humans and animals from exposure. Studies have shown that the release of treated effluent from Wastewater Treatment Plants (WWTPs) contributed to the majority of MPs found in the water bodies (Arimi 2018; Sabbah et al. 2019; Freeman et al. 2020). According to Sabbah et al. (2019) and Freeman et al. (2020), there is high variation in MPs concentration obtained per litre (0.005-91 MP particles $\mathrm{L}^{-1}$ and 0-447 MP particles $\mathrm{L}^{-1}$ ) in final effluents from different WWTPs around the world. This has led to strict regulations and standards by most environmental regulatory bodies regarding the discharge of effluent from wastewater treatment plants into the environment (Visvanathan et al. 2000; Arimi 2018; Sabbah et al. 2019; Cuartucci 2020; Paredes et al. 2021). Thus, there is need for improving the existing technologies or the use of advance technology that is capable of removing MPs of different sizes, shapes, polymer and densities from the influent and effluent at all stages of wastewater treatment to meet the effluent discharge and reuse standards (Arimi 2018; Cuartucci 2020; and Rathilal 2020). There is currently no restriction in any regulation worldwide and neither is there any technique that is standardized for the elimination of MPs (Shen et al. 2020). However, there are several methods such as dissolved air flotation, electrocoagulation, metal-based coagulation, membrane biological reactor, rapid sand filter, inorganic-organic hybrid silica gels, reverse osmosis etc. that have been applied in many studies. Recent development in the membrane bioreactor technique involves the use of bacteria to degrade the plastic. Dawson et al. (2018) demonstrated that the exposure of MPs to Antartic Krill (Euphasiasuperba) was able to reduce MPs from 31.5 to less than $1 \mu \mathrm{m}$. Poerio et al. (2019) in their review explained that the isolation of a novel bacterium (Ideonella sakaiensis) was able to efficiently convert PET in the less dangerous monomers (terephthalic acid and ethylene glycol).

Ideonella sakaiensis is a gram-negative, aerobic, and rod-shaped bacteria that grow optimally at $\mathrm{pH} 7-7.5$ and a temperature of $30-37^{\circ} \mathrm{C}$ (Yoshida et al. 2016). Recently, the bacterial strain I. sakaiensis 201-F6 was discovered and shown to grow on low-crystallinity PET films (Palm et al. 2019). The bacteria cells hold fast to the PET surface and utilize an emitted PET hydrolase, or PETase, to reduce the PET into mono(2-hydroxyethyl)terephthalic corrosive (MHET), a heterodimer made out of terephthalic acid (TPA) and ethylene glycol. The I. sakaiensis PETase works by hydrolyzing the ester bonds present in PET with high particularity. The subsequent MHET is then reduced into its two monomeric constituents by a 
lipid-moored MHET hydrolase chemical, or MHETase, on the cell's external membrane. Ethylene glycol is promptly taken up and utilized by $I$. sakaiensis and numerous other bacteria (Pearce and Heydeman 1980). Terephthalic acid, a more obstinate compound, is brought into the I. sakaiensis cell through the TPA carrier protein. Once in the cell, the sweet-smelling TPA particle is oxidized by TPA-1,2-dioxygenase and 1,2-dihydroxy3,5-cyclohexadiene-1,4-dicarboxylate dehydrogenase into an intermediate of catechol. The catechol ring is then divided by PCA 3,4-dioxygenase before the compound is incorporated into other metabolic pathways (for example TCA cycle). Thus, both particles obtained from the PET are utilized by the cell to create energy and to construct vital biomolecules. In the long run, the acclimatized carbon might be mineralized to carbon dioxide and delivered into the atmosphere (Yoshida et al. 2016).

Natural enzymes have been shown to have the ability to catalyze the hydrolysis of microplastics as an environmentally friendly alternative to chemical recycling methods (Wei et al. 2014; Wei and Zimmermann 2017). These enzymes occur in several saprotrophic organisms, including fungi (Dimarogona et al. 2015) and bacteria (Fecker et al. 2018), and often inhabit environments enriched in plant-based organic matter or plastic debris which when required can be used as a main carbon source for cell growth activities (Yoshida et al. 2016). The degradation of MPs by bacteria is made possible by the production of these enzymes which reduce the plastics to simpler compounds. In this study, in silico analysis of the binding affinity of some MP compounds on PET hydrolase enzyme of I. sakaiensis was performed. The selectivity of the MPs by the enzyme was evaluated from the binding free energy values of the compounds. The data from this study would significantly advance the current understanding of the action of PET hydrolase enzyme on the selected MPs.

\section{Methods}

Identification and preparation of ligands

Microplastic compounds were downloaded from the PubChem database and used for the study. Their 3D structure-data files (SDF) were downloaded, and used for the docking analysis.

\section{Identification and preparation of enzyme target}

The enzyme PET hydrolase of $I$. sakaiensis (PDB ID: 6ANE) with resolution $2.02 \AA$ was identified from literature and used as a target in this study. The enzyme was retrieved from the Protein Data Bank (PDB) and consisted of three chains, A, B, and C. Chain A of the protein was used for the docking studies in other to improve the accuracy of the ligand binding (Sasikala and Meena
2016). The interfering crystallographic water molecules and minimization of the protein was done using UCSF Chimera 1.14 (Pettersen et al. 2004; Duru et al. 2020,2021a). The active sites on the enzyme were identified using Biovia Discovery studio 4.5 (BIOVIA 2020).

\section{Docking studies}

The multiple ligand docking of the microplastic compounds on the enzyme targets was done with Autodock Vina in PyRx software version 0.8 (Tsao et al. 2020; Duru and Duru 2020; Duru et al. 2021b). Blind docking of the microplastic compounds at the enzyme cavities was performed to give the ligands unhindered access to interact with sites where they had minimum energy. The center grid box was set to the dimension center $x$ : -22.083 , center $y$ : -18.658 , center $z$ : -22.040 , and size $x$ : 48.492, size $y: 55.549$, size $z: 52.328$. The results in terms of binding free energy $(\Delta G)$ for each compound were obtained.

\section{Analysis of protein-ligand interactions}

Hydrogen bonding and other hydrophobic interactions between the enzyme-ligand complex of the compounds was visualized using Biovia Discovery studio 4.5.

\section{Results}

The binding affinity of the microplastic compounds on the PET hydrolase enzyme of this bacterium is shown in Table 1.

The binding positions of the microplastic compounds relative to the active sites on $I$. sakaiensis are shown in Fig. 1 and the interactions of the compounds with the amino acid residues on the enzyme target are shown in Table 2.

Table 1 Binding affinity of microplastic compounds on the enzyme target of I. sakaiensis

\begin{tabular}{|l|l|c|c|}
\hline \multicolumn{1}{|c|}{ Compound } & $\begin{array}{c}\text { PubChem } \\
\text { CID }\end{array}$ & Structure & $\begin{array}{c}\Delta G \text { Energy } \\
\text { (Kcal/mol) }\end{array}$ \\
\hline Polyamide & 36070 & & -4.4 \\
\hline Polyvinyl chloride & 6338 & & \\
\hline $\begin{array}{l}\text { Polyethylene } \\
\text { terephthalate }\end{array}$ & 18721140 & & \\
\hline $\begin{array}{l}\text { Polymethyl } \\
\text { methacrylate }\end{array}$ & 6658 & & \\
\hline Polyurethane & 12254 & & \\
\hline
\end{tabular}



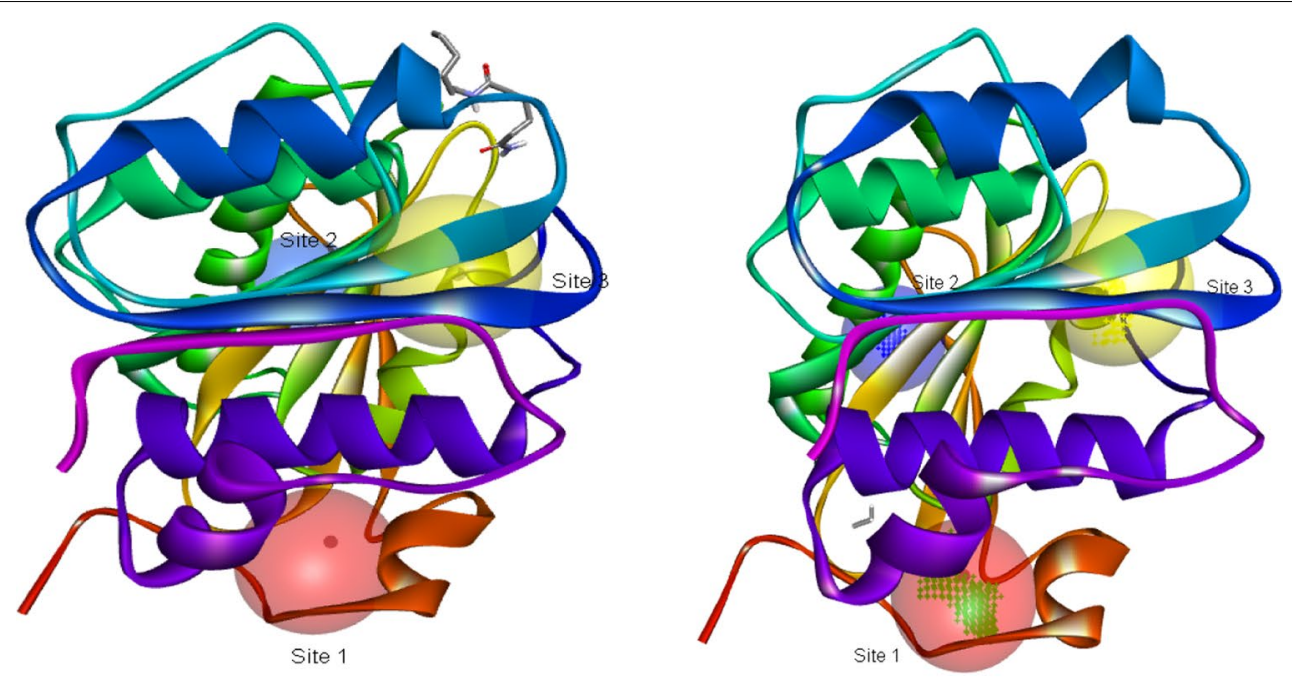

A

B
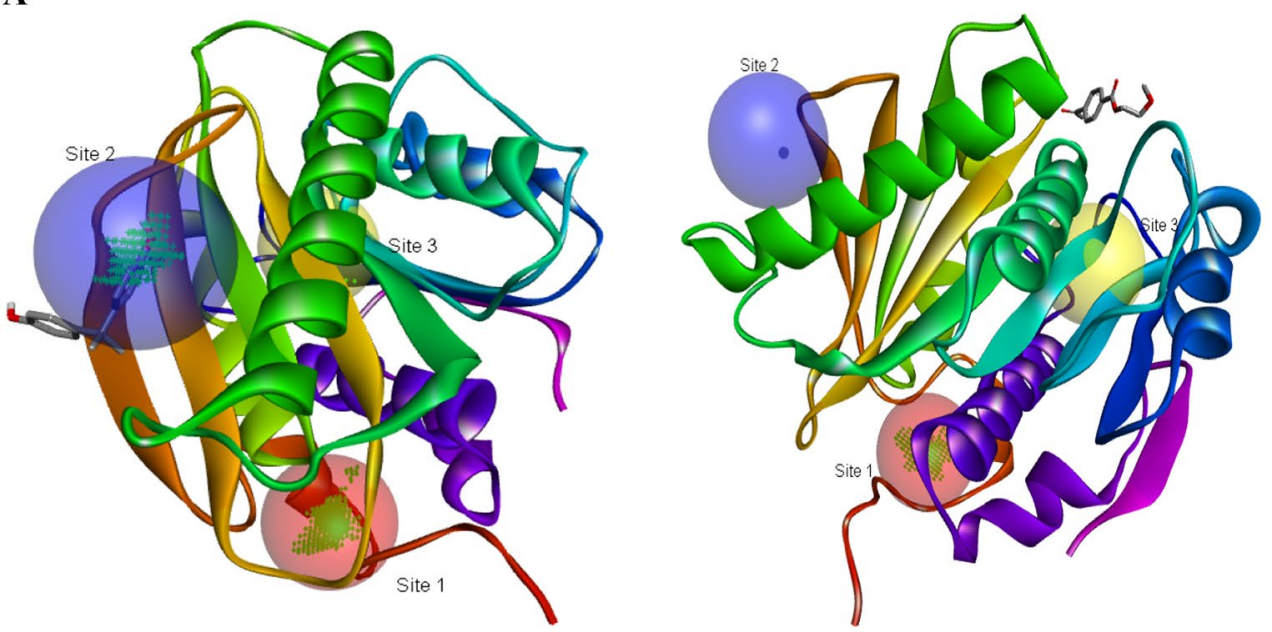

C

D
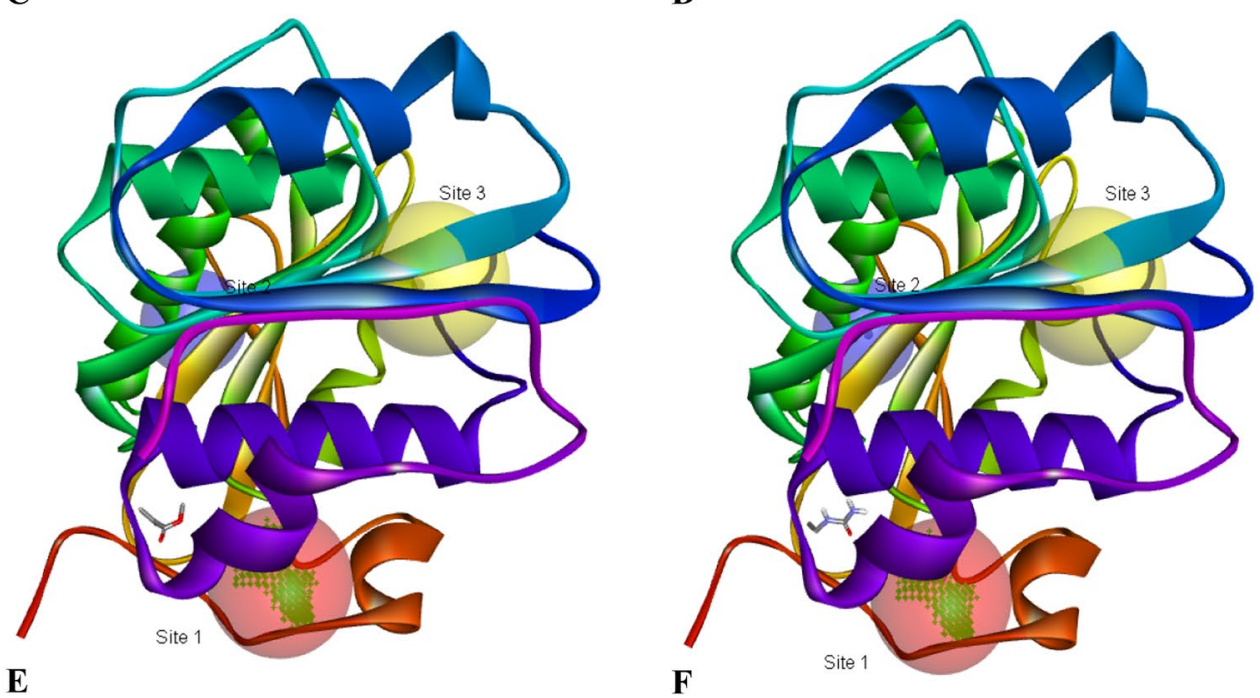

Fig. 1 Binding of microplastic compounds at different sites on I. sakaiensis 
Table 2 Interactions of microplastic compounds with protein residues on I. sakaiensis enzyme

\begin{tabular}{|c|c|c|}
\hline Compound & Protein-ligand interactions & Interacting amino-acid residues \\
\hline Polyamide & A:60 & TYR60; MET134; TRP158; ILE181 \\
\hline Polyvinyl chloride & 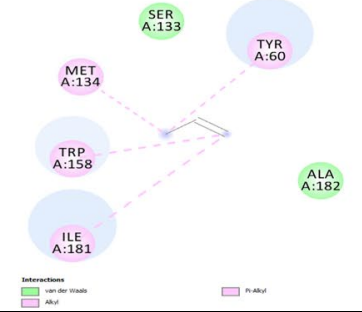 & $\begin{array}{l}\text { TYR60; SER133; MET134; TRP158; } \\
\text { ILE181; ALA182 }\end{array}$ \\
\hline Polycarbonate & 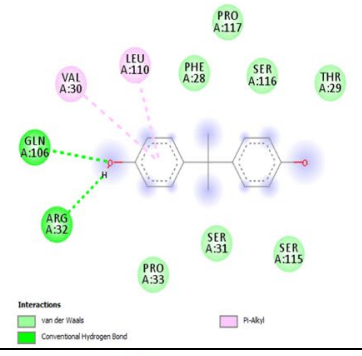 & $\begin{array}{lrr}\text { PHE28; } & \text { THR29; VAL30; } & \text { SER31; } \\
\text { ARG32; PRO33; GLN106; LEU110; } \\
\text { SER115; SER116; PRO117 }\end{array}$ \\
\hline Polyethylene terephthalate & (II:) & $\begin{array}{l}\text { TYR60; THR61; ALA62; TPR132; } \\
\text { SER133; MET134; TRP158; ILE181; } \\
\text { ALA182; HIS210 }\end{array}$ \\
\hline Polymethyl methacrylate & 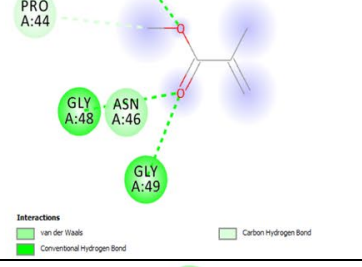 & $\begin{array}{l}\text { PRO44; ASN46; ALA47; GLY48; } \\
\text { GLY49; GLY120; LYS121 }\end{array}$ \\
\hline Polyurethane & (A:A) & $\begin{array}{llll}\text { PRO44; } & \text { THR45; } & \text { ASN46; } & \text { ALA47; } \\
\text { GLY49; } & \text { THR50; } & \text { VAL51; } & \text { GLY120; } \\
\text { LYS121 } & & & \end{array}$ \\
\hline
\end{tabular}




\section{Discussions}

Enzymes are biocatalysts which participate in a reaction, act on a particular substrate, and accelerate the process of conversion of that substrate into a valuable product. The possibility of degradation of plastic that pollutes our environment by microorganisms lead to an increased interest towards the basic mechanism by which microorganism are able to degrade this very tough polymer. The chain $\mathrm{A}$ of I. sakaiensis (Fig. 2) had three active sites which were labeled as site 1 , site 2 , and site 3 . The binding free energy of the compounds increased in the order polyvinylchloride $<$ polyurethane $<$ polymethyl methacrylate $<$ polyamide $<$ polyethylene terephthalate $<$ polycarbonate.

Polycarbonates (PC) are thermoplastic polymers that contain the carbonate group in their chemical structure. They are strong and tough, and some grades are optically transparent. They are easily worked, molded, and thermoformed, which make them to find many applications like in the production of water dispenser bottles, laboratory safety goggles, compact discs, etc. At slightly high temperature and humidity, they can be hydrolyzed to bis-phenol A (BPA), a compound that is currently on the list of potential environmental hazardous chemicals (Mazhandu et al. 2020). The binding free energy of polycarbonate on the PET hydrolase enzyme was the highest with value $-5.7 \mathrm{kcal} / \mathrm{mol}$ and showed that its hydrolysis by the bacterial enzyme was the most energy efficient of all the studied microplastic compounds. The binding

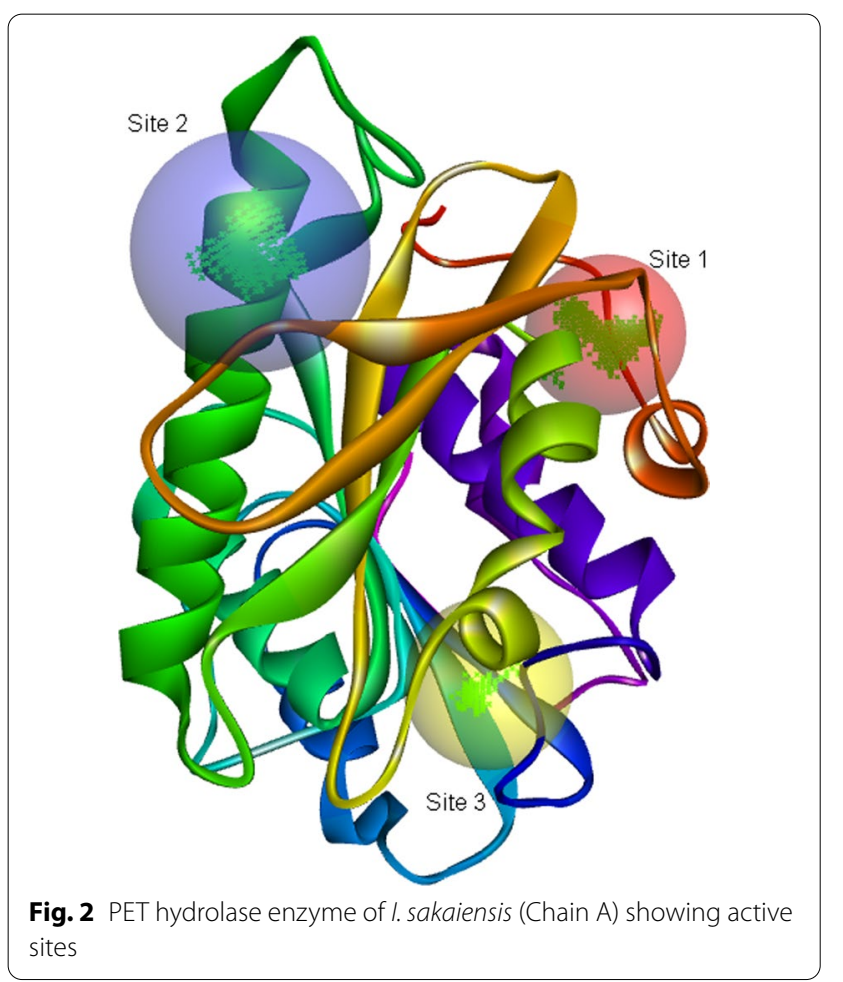

of the compound occurred in active site 2 of the enzyme and was the only compound that interacted with an active site on the enzyme.

Polyethylene terephthalate (PET) is a thermoplastic polymer resin of the polyester family, commonly used in fibres for clothing, to manufacture bottles for water and soft drinks, as well as packaging material used for selling fruits, hardware etc. About $18 \%$ of the world's polymer production is made up of PET and it is the fourth most produced polymer after polyethylene, polypropylene, and polyvinyl chloride (Ji 2013). When PET is dumped in the environment after use, it discolours after sometime, followed by chain scission resulting to reduced molecular weight and deposition in the environment (Tournier et al. 2020). The binding free energy of the compound on the enzyme was $-5.2 \mathrm{kcal} / \mathrm{mol}$, and the second highest of all the studied compounds. Its interaction with the enzyme occurred at an allosteric site close to active site 3 .

Polyamides (PA) are proteins which occur naturally as wool and silk. Synthetic polyamides can occur as sodium poly(aspartate), nylons, and aramids, which are used in textiles, carpets, sportswear, and in automotive industry due to their high strength and durability (Machado et al. 2019). The transportation industry consumes about $35 \%$ of all manufactured polyamides. These plastics are deposited in the environment in large amounts around automobile junk yards where many condemned vehicles are allowed to degrade naturally. The binding free energy of the compound on the enzyme was $-4.4 \mathrm{kcal} /$ mol which is significantly lower than the values for polycarbonate and polyethylene terephthalate. The binding of the compound occurred at an allosteric site close to active site 3 and similar to the binding position of polyethylene terephthalate as both interacted with TYR60, MET134, TRP158, and ILE181 residues.

Polymethyl methacrylate (PMMA) also known as acrylic is a transparent thermoplastic often used in sheet form as a light weight or shatter-resistant substitute to glass. It is an economical alternative to polycarbonate when transparency, tensile strength, impact strength, chemical and heat resistance are required. The binding free energy of this compound to the enzyme was - $3.8 \mathrm{kcal} / \mathrm{mol}$ and its binding position was close to active site 1 .

Polyurethane (PUR) is a thermosetting polymer composed of organic units joined by urethane links. They are used in the manufacture of rigid foam insulation panels, high-resilience foam seating, hoses, and condoms (Figovsky et al. 2016). Over time, polyurethane crumbles to lower molecular weight forms due to hydrolysis. Its binding free energy was $-3.5 \mathrm{kcal} / \mathrm{mol}$ and occurred close to active site 1 , in the same binding pocket as polymethyl methacrylate. The interacting amino acid residues for 
the two plastics were PRO44, ASN46, ALA47, GLY49, GLY120, and LYS121, suggesting that the action of the enzyme on the two plastics follow the same mechanism, with polymethyl methacrylate having a higher selectivity than polyurethane.

Polyvinyl chloride (PVC) is the world's third-most widely produced synthetic plastic polymer. It is used in construction for pipes, food-covering sheets, flooring, electrical cables, imitation leather, signage, inflatable products, and many others (Wilkes et al. 2005). Its degradation drastically reduces its average molecular weight, thereby weakening the material. Weathering degradation results in their surface embrittlement yielding microplastics that continue on in the environment. The binding free energy of this plastic was $-2.2 \mathrm{kcal} / \mathrm{mol}$ and the lowest of all the studied plastics. The very low affinity of this plastic suggested that it cannot be easily degraded in the environment by PET hydrolase of I. sakaiensis.

\section{Conclusions}

Computation investigation of the hydrolysis potentials of some selected microplastic compounds by the chain A of PET hydrolase enzyme of I. sakaiensis was performed. The binding affinity of polycarbonate was the highest with value $-5.7 \mathrm{kcal} / \mathrm{mol}$ and occurred at an active site in the enzyme. Polyethylene terephthalate and polyamide were the next highest with binding affinities $-5.2 \mathrm{kcal} /$ $\mathrm{mol}$ and $-4.4 \mathrm{kcal} / \mathrm{mol}$ respectively, and their interactions occurred at the same allosteric site in the enzyme. The binding affinity of polyvinyl chloride was the lowest, with value $-2.2 \mathrm{kcal} / \mathrm{mol}$ and indicated that the hydrolysis of this plastic by the enzyme could be inefficient. These findings suggest that the use of PET hydrolase enzyme in microplactic hydrolysis would serve well in areas such as soil and marine environments where the plastic deposits are majorly composed of polycarbonate and polyethylene terephthalate.

\begin{abstract}
Abbreviations
MP: Microplastic; NP: Nanoplastic; PP: Polypropylene; PC: Polycarbonate; PSE: Expanded polystyrene; PSU: Polyarylsulfone; PS: Polystyrene; TPE: Thermoplastic elastomer; PET: Polyethylene terephthalate; PMMA: Polymethyl methacrylate; PVC: Polyvinyl chloride; PP: Polypropylene; PA: Polyamide; PUR: Polyurethane; WWTP: Wastewater Treatment Plant; SDF: Structure-data files; PDB: Protein Data Bank; TYR: Tyrosine; MET: Methionine; TRP: Tryptophan; ILE: Isoleusine; SER: Serine; ALA: Alanine; PHE: Phenylalanine; THR: Threonine; VAL: Valine; ARG: Arginine; PRO: Proline; GLN: Glutamine; LEU: Leucine; HIS: Histidine; ASN: Asparagine; GLY: Glycine; LYS: Lysine.
\end{abstract}

\section{Acknowledgements}

The authors are grateful to ChemSolvers Research and Computational Laboratory Studio, Owerri, Nigeria, for assisting in the in silico studies.

\section{Authors' contributions}

CED conceived, designed, and wrote the research. IAD carried out the docking studies. CEE prepared the final proof and corrections. All authors have approved the manuscript in the present form, and gave the permission to submit the manuscript for publication. All authors read and approved the final manuscript.

\section{Funding}

No funds, grants, or other support was received.

Availability of data and materials

All data generated or analyzed during this study are included in this published article.

\section{Declarations}

Ethics approval and consent to participate

Not applicable.

Consent for publication

Not applicable.

\section{Competing interests}

The authors declare that they have no competing interests.

\section{Author details}

${ }^{1}$ Surface Chemistry and Environmental Technology (SCENT) Research Unit, Department of Chemistry, Imo State University, PMB 2000, Owerri, Imo State, Nigeria. ${ }^{2}$ Department of Chemistry, Federal University of Technology Owerri, PMB 1526, Owerri, Imo State, Nigeria. ${ }^{3}$ Department of Chemistry, Imo State University, PMB 2000, Owerri, Imo State, Nigeria.

Received: 12 January 2021 Accepted: 1 June 2021

Published online: 08 June 2021

\section{References}

Abd-Aziz NH, Alias S, Bashar NAM, Amir A, Abdul-Talib S, Tay CC (2019) A short review: Potential use of plastic waste as adsorbent for various pollutants. In: AlP conference proceedings, vol 2124, pp 020034. https://doi.org/10. 1063/1.5117094

Aggarwal P (2019) Interactive environmental education book VIII. Pitambar Publishing Company Pvt, Ltd, New Delhi, India, p 86.

Arimi MM (2018) Particle size distribution as an emerging tool for the analysis of wastewater. Environ Technol Rev 7(1):274-290

BIOVIA (2020) Dassault Systemes, San Diego, Discovery studio modeling environment

Campanale C, Massarelli C, Savino I, Locaputo V, Uricchio VF (2020) A detailed review study on potential effects of microplastics and additives of concern on human health. Int J Environ Res Public Health 17(4):1212. https:// doi.org/10.3390/ijerph17041212

CIEL (2019a) Sweeping new report on global environmental impact of plastics reveals severe damage to climate. https://www.ciel.org/news/plasticand climate/. Accessed 15 May 2019

CIEL (2019b) Plastic proliferation threatens the climate on a global scale. Plastic \& climate: the hidden costs of a plastic planet. Executive summary. https://www.ciel.org/wp-content/uploads/2019/05/Plastic-and-ClimateExecutive-Summary-2019.pdf. Accessed 24 May 2019

Cuartucci M (2020) Ultrafiltration, a cost-effective solution for treating surface water to potable standard. Water Pract Technol 15(2):426-436

Diaz-Torres ER, Ortega-Ortiz CD, Silva-Iniguez L, Nene-Preciado A, Orozco ET (2017) Floating marine debris in waters of the Mexican Central Pacific. Mar Pollut Bull 115:225-232

Dimarogona M, Nikolaivits E, Topakas E (2015) Structural and functional studies of a Fusarium oxysporum cutinase with polyethylene terephthalate modification potential. Biochim Biophys Acta 1850:2308-2317

Dawson AL, Kawaguchi S, King CK, Townsend KA, King R, Huston WM, Bengtson NSM (2018) Turning microplastics into nanoplastics through digestive fragmentation by antarctic krill. Nat Commun 9(1):1001. https:// doi.org/10.1038/s41467-018-03465-9

Duru IA, Duru CE (2020) Molecular docking of compounds in the essential oil of Ocimium gratissimum leaf against PIM-1 kinase of Escherichia coli. EJ-CHEM 1(6):1-4 
Duru CE, Duru IA, Bilar A (2020) Computational investigation of sugar fermentation inhibition by bergenin at the pyruvate decarboxylate isoenzyme 1 target of Scharomyces cervisiae. J Med Plants Stud 8(6):21-25

Duru CE, Duru IA, Adegboyega AE (2021a) In Silico identification of compounds from Nigella sativa seed oil as potential inhibitors of SARS-CoV-2 targets. Bull Natl Res Cent 45:57. https://doi.org/10.1186/ S42269-021-00517-X

Duru CE, Duru IA, García BAA, Enenebeaku UE (2021b) Computational modeling of the activity of metronidazole against EhGa1 of Entamoeba histolytica enhanced by its copper and zinc complexes. Chem Africa. https://doi.org/10.1007/s42250-021-00245-9

Enyoh CE, Verla AW, Verla EN (2019a) Uptake of microplastics by plant: a reason to worry or to be happy? World Sci News 131:256-267

Enyoh CE, Verla AW, Verla EN, Ibe FC, Amaobi CE (2019b) Airborne microplastics: a review study on method for analysis, occurrence, movement and risks. Environ Monit Assess 191:668. https://doi.org/10.1007/ s10661-019-7842-90

Enyoh CE, Leila S, Andrew WV, Evelyn NV, Wang Q, Tanzin C, Marcel P (2020) Microplastics exposure routes and toxicity studies to ecosystems: an overview. Environ Anal Health Toxicol 35(1):1-10

Ezugbe EO, Rathilal S (2020) Membrane technologies in wastewater treatment: a review. Membranes 10:89. https://doi.org/10.3390/membranes 100500 89

Fecker T, Galaz-Davison P, Engelberger F, Narui Y, Sotomayor M, Parra LP, Ramírez-Sarmiento CA (2018) Active site flexibility as a hallmark for efficient pet degradation by I. sakaiensis PETase. Biophys J 114(6):1302-1312

Figovsky OL, Leikin AD, Shapovalov LD (2016) Non-isocyanate polyurethanes-yesterday, today and tomorrow. ISJAEE 3-4:95-108

Freeman S, Booth AM, Sabbah I, Tiller R, Dierking J, Klun K, Angel DL (2020) Between source and sea: the role of wastewater treatment in reducing marine microplastics. J Environ Manag 266:110642. https://doi.org/10. 1016/j.jenvman.2020.110642

Harris PT, Westerveld L, Nyberg B, Maes T, Macmillan-Lawler M, Appelquist LR (2021) Exposure of coastal environments to river-sourced plastic pollution. Sci Total Environ 769:145222. https://doi.org/10.1016/j.scitotenv. 2021.145222

Jambeck JR, Geyer R, Wilcox C, Siegler TR, Perryman M, Andrady A, Narayan $R$, Law KL (2015) Plastic waste inputs from land into the ocean. Science 347(6223):768-771

Ji LN (2013) Study on preparation process and properties of polyethylene terephthalate (PET). Appl Mech Mater 312:406-410

Karami A, Abolfazl G, Cheng KC, Vincent L, Tamara SG, Babak S (2017) The presence of microplastics in commercial salts from different countries. Sci Rep 7:46173. https://doi.org/10.1038/srep46173

Li J, Zhang K, Zhang H (2018) Adsorption of antibiotics on microplastics. Environ Pollut 237:460-467. https://doi.org/10.1016/j.envpol.2018.02.050

Li Y, Li M, Li Z, Yang L, Liu X (2019) Effects of particle size and solution chemistry on triclosan sorption on polystyrene microplastic. Chemosphere 231:308-314

Machado AA, Lau CW, Kloas W, Bergmann J, Bachelier JB, Faltin E, Becker R, Görlich AS, Rillig MC (2019) Microplastics can change soil properties and affect plant performance. Environ Sci Technol 53(10):6044-6052

Mazhandu ZS, Muzenda E, Mamvura TA, Belaid M, Nhubu T (2020) Integrated and consolidated review of plastic waste management and bio-based biodegradable plastics: challenges and opportunities. Sustainability 12(20):1-57. https://doi.org/10.3390/su12208360

Narciso-Ortiz L, Coreño-Alonso A, Mendoza-Olivares D, Lucho-Constantino CA, Lizardi-Jiménez MA (2020) Baseline for plastic and hydrocarbon pollution of rivers, reefs, and sediment on beaches in Veracruz State, México, and a proposal for bioremediation. Environ Sci Pollut Res 27(18):23035-23047. https://doi.org/10.1007/s11356-020-08831-z

Palm GJ, Reisky L, Böttcher D, Muller H, Michels EAP, Walczak MC, Berndt L, Weiss MS, Bornscheuer UT, Weder G (2019) Structure of the plasticdegrading Ideonella sakaiensis MHETase bound to a substrate. Nat Commun 10:1717. https://doi.org/10.1038/s41467-019-09326-3
Paredes M, Rafaela V, Tito C, Cristian C, Enyoh CE (2021) Microplastics from degradation of tires in sewer networks of the city of Riobamba. Ecuador Environ Eng Res 26(5):200276. https://doi.org/10.4491/eer.2020.276

Pearce BA, Heydeman MT (1980) Metabolism of di(ethylene glycol) [2-(2'-Hydroxyethoxy)ethanol] and other short poly(ethylene glycol)s by gram-negative bacteria. J Gen Microbiol 118(1):21-27

Pettersen EF, Goddard TD, Huang CC, Couch GS, Greenblatt DM, Meng EC, Ferrin TE (2004) UCSF Chimera—a visualization system for exploratory research and analysis. J Comput Chem 25(13):1605-1612

Poerio T, Piacentini E, Mazzei R (2019) Membrane processes for microplastic removal. Molecules 24(22):4148. https://doi.org/10.3390/molecules2 4224148

Sabbah I, David EB, Habiby M, Haddad E, Hassanin M, Angel D (2019)Technical report on the quantities, types and size spectra of MP particles in WWTP effluent. Deliverable. Go Jelly. EU project. Work Package 5, Activity T5.1

Sasikala RP, Meena KS (2016) Molecular docking studies and ADMET properties of compounds from Physalis minima L. leaves root and fruit. Innov J Life Sci 4:21-25

Shen M, Song B, Zhu Y, Zeng G, Zhang Y, Yang Y, Yi H (2020) Removal of microplastics via drinking water treatment: Current knowledge and future directions. Chemosphere 251:126612. https://doi.org/10.1016/j.chemo sphere. 2020.126612

Tournier V, Topham CM, Gilles A, David B, Folgoas C, Moya-Leclair E, Kamionka E, Desrousseaux M, Texier H, Gavalda S, Cot M, Guemard E, Dalibey M, Nomme J, Cioci G, Barbe S, Chateau M, Andre I, Duquesne S, Marty A (2020) An engineered PET depolymerase to break down and recycle plastic bottles. Nature 580:216-219

Tsao YC, Chang YJ, Wang CH, Chen L (2020) Discovery of isoplumbagin as a novel NQO1 substrate and anti-cancer quinone. Int J Mol Sci 21(12):4378. https://doi.org/10.3390/ijms21124378

Verla AW, Enyoh CE, Verla EN (2019a) Microplastics, an emerging concern: a review of analytical techniques for detecting and quantifying microplatics. Anal Methods Environ Chem J 12:15-32

Verla AW, Enyoh CE, Verla EN, Nwanorh KO (2019b) Microplastic-toxic chemical interaction: a review study on quantified levels, mechanism and implication. SN Appl Sci 1:1400. https://doi.org/10.1007/s42452-019-1352-0

Visvanathan C, Aim RB, Parameshwaran K (2000) Membrane separation bioreactors for wastewater treatment. Crit Rev Environ Sci Technol 30(1):1-48

Wang Q, Enyoh CE, Chowdhury T, Chowdhury MH (2020) Analytical techniques, occurrence and health effects of micro and nano plastics deposited in street dust. Int J Environ Anal Chem. https://doi.org/10. 1080/03067319.2020.1811262

Wei R, Zimmermann W (2017) Biocatalysis as a green route for recycling the recalcitrant plastic polyethylene terephthalate. Microb Biotechnol 10:1302-1307

Wei R, Oeser T, Zimmermann W (2014) Synthetic polyester-hydrolyzing enzymes from thermophilic actinomycetes. Adv Appl Microbiol 89:267-305

Wilkes CE, Summers JW, Daniels CA, Berard MT (2005) PVC Handbook. Hanser Verlag, Munich, Germany

Wright SL, Kelly FJ (2017) Plastic and human health: a micro issue? Environ Sci Technol 51(12):6634-6647

Yoshida S, Hiraga K, Oda K (2016) A bacterium that degrades and assimilates poly(ethylene terephthalate). Science 351:1196-1199

Zhang H, Sabolc P, Mark AT, Kenneth GB, Neil AJ, Stuart WG (2020) A review of the potential utilization of plastic waste as adsorbent for removal of hazardous priority contaminants from aqueous environments. Environ Poll 258:113698. https://doi.org/10.1016/j.envpol.2019.1136980269-7491

\section{Publisher's Note}

Springer Nature remains neutral with regard to jurisdictional claims in published maps and institutional affiliations. 